\title{
Synthetic Polypeptide Derived from Viral Macrophage Inflammatory Protein II Inhibit the Uninfected CD4+ T Cells Apoptosis Induced by HIV-1 Extracellular Nef
}

\author{
Gui-Jie An, Xiu-Ying Li, Han-Xiao Sun*, Sha Liu, Jing-Guang Zhou, Qing Ding, \\ Pi-Jin Wei and Guang Zhang \\ Institute of Genomic Medicine, College of Pharmacy, Jinan University, Guangzhou 510632, China
}

*For correspondence: Email: sunhx718@163.com; Tel: +86-020-38375022

Received: 19 December 2013

Revised accepted: 30 April 2014

\begin{abstract}
Purpose: To evaluate the potential role and cellular mechanism of the CXCR4 antagonist (N15P) derived from the $\mathrm{N}$-terminal of viral macrophage inflammatory protein-II (VMIP-II) on the apoptosis induced by HIV-1 extracellular nef protein in vitro.

Method: Peripheral blood mononuclear cells (PBMCs) and Jurkat cells were treated with HIV-1 nef protein alone or together with N15P at different doses and time points. The competitive binding effect of N15P against nef was assessed via radioligand binding assays. Apoptosis was evaluated via terminal deoxynucleotidyl transferase biotin-dUTP nick end labeling (TUNEL) assay. The level of nuclear FOXO3a and phospho-FOXO3a was assessed by Western blotting.

Results: The interaction of ${ }^{125} \mathrm{I}$-nef with Jurkat cells was inhibited by $N 15 P$ in a dose-dependent manner, with $I C_{50}$ value of $0.3516 \mathrm{ng} / \mathrm{ml}$. N15P protect against nef protein-induced apoptosis in a timeand concentration- dependent manner. The proapoptotic effect of extracellular nef protein in cells was associated with FOXO3a pathway and the changes in intracellular processes were blocked by N15P in a dose-dependent manner.

Conclusion: N15P inhibits the apoptosis of uninfected $C D 4^{+} T$ lymphocytes induced by HIV-1 extracellular nef protein. Therefore, N15P is a potential effective CXCR4 antagonist in the course of HIV and could prevent or delay the onset of AIDS.
\end{abstract}

Keywords: HIV-1, Nef, vMIP-II, Bystander lymphocytes, Apoptosis, FOXO3a, CXCR4 antagonist, Macrophage, Inflammation

Tropical Journal of Pharmaceutical Research is indexed by Science Citation Index (SciSearch), Scopus, International Pharmaceutical Abstract, Chemical Abstracts, Embase, Index Copernicus, EBSCO, African Index Medicus, JournalSeek, Journal Citation Reports/Science Edition, Directory of Open Access Journals (DOAJ), African Journal Online, Bioline International, Open-J-Gate and Pharmacy Abstracts

\section{INTRODUCTION}

Apoptosis of uninfected bystander cells is a key element of HIV pathogenesis and believed to be the driving force behind the selective depletion of $\mathrm{CD}^{+} \mathrm{T}$ cells leading to immunodeficiency. In this regard, inhibition of uninfected cells death is therefore considered to prevent or delay the onset of AIDS.
Several HIV encoded proteins have been implicated in the process of HIV-1 induced uninfected $\mathrm{CD}^{+}{ }^{+} \mathrm{T}$ cells apoptosis, such as gp120 [1], tat [2], the protease [3], vpr [4] and nef [5]. Recent evidence suggests that nef is found in abundance in the sera of HIV-infected individuals and induce the apoptosis of uninfected $\mathrm{CD}^{+} \mathrm{T}$ by interacting with CXCR4 surface receptors [68]. But, the molecular basis of how this phenomenon is triggered in uninfected $\mathrm{CD}^{+} \mathrm{T}$ 
cells is not completely understood. Previous studies demonstrated that FOXO3a pathway was involved in the survival and maintenance of memory CD4 ${ }^{+}$T-cells [9], memory B cells [10], macrophages [11] during HIV infection. Thus, we speculate that the $\mathrm{FOXO} 3$ a signal pathway might have a possible role in nef-induced bystander apoptosis. Furthermore, a better understanding of how viral proteins interact with or hijack and alter host cell metabolism might provide important insights for understanding of AIDS pathogenesis.

Viral macrophage inflammatory protein-II (VMIPII), encoded by human herpesvirus-8, has garnered interest because of its ability to bind to multiple chemokine receptors, including CCR5 and CXCR4 [12]. Based on our previously published work on vMIP-II [13], we synthesized a novel and small molecule selective CXCR4 antagonist N15P (LGASWHRPDKCCLGY) derived from the N-terminal of VMIP-II [14]. In this study, we evaluated the inhibitory effects of N15P on nef-induced uninfected $\mathrm{CD}^{+} \mathrm{T}$ cells apoptosis and the role of $\mathrm{FOXO} 3 a$ signal pathway. These results indicate that N15P has therapeutic potential for uninfected $\mathrm{CD} 4^{+} \mathrm{T}$ cells apoptosis during HIV infection.

\section{EXPERIMENTAL}

\section{Reagents and materials}

Anti-phospho-FOXO3a $\left(\mathrm{Ser}^{253}\right)$ and antiFOXO3a were purchased from Cell Signaling Technology (USA). Anti- $\beta$-actin was from Santa Cruz (La Jolla, CA). HIV-1 Nef was from ABcam (USA). The radiolabelling of Nef and the synthesis of N15P were entrusted to the Shanghai YaoQiang Bio-Tech Co, Ltd, China (the final product was at least $95 \%$ pure). All the inhibitors were dissolved in dimethyl sulfoxide (DMSO) (Sigma, USA) with the final concentration not exceeding $0.1 \%$.

\section{Cells and culture conditions}

Jurkat cells (Chinese Academy of Sciences, China) were maintained in RPMI 1640 medium (Invitrogen, USA) supplemented with $10 \%$ fetal bovine serum, streptomycin $(100 \mathrm{U} / \mathrm{mL})$, penicillin $(100 \mathrm{U} / \mathrm{mL})$, L-glutamine $(2 \mathrm{mM})$, and HEPES-buffered saline solution (30 $\mu \mathrm{M})$. Peripheral blood was drawn from healthy volunteers (18 - 25 years old). PBMCs were isolated from blood samples by Ficoll-Histopaque density gradient centrifugation and cultured in RPMI 1640 medium (Invitrogen, USA) supplemented with $10 \%$ fetal bovine serum
(Sigma, USA) and $1 \mu \mathrm{g} / \mathrm{ml}$ phytohemagglutinin (Sigma, USA). Cell viability was determined by trypan blue dye exclusion assay from an optimal suspension of $1 \times 10^{6} \mathrm{cells} / \mathrm{ml}$. In accordance with ethical standards, the healthy volunteers were properly informed of the study and signed an agreement authorizing the test.

\section{Competitive binding of N15P against Nef}

Radioligand binding assay was performed as described previously [15]. Briefly, $1 \mathrm{mg}$ wheat germ agglutinin-coated SPA beads (Amersham Pharmacia Biotech, USA) in $100 \mu \mathrm{L}$ of binding assay buffer were prepared in a 96-well microtiter plate. N15P was dissolved in $100 \%$ DMSO solution and $1 \mu$ of that solution was added to each well, and then cells $\left(1 \times 10^{6}\right.$ cells, $50 \mu \mathrm{L})$ were also transferred to wells. Reactions were started by adding $50 \mu \mathrm{L}$ of 100 pM ${ }^{125}$ I-nef at room temperature. One hour later, radioactivity was counted. In all experiments, each data point was assayed in duplicate. Subsequent data analyses were carried out using the program GraphPad Prism 5 (GraphPad, San Diego, CA, USA)

\section{TUNEL staining}

Freshly isolated PBMCs $\left(1 \times 10^{6}\right.$ cells $)$ and Jurkat $\left(1 \times 10^{6}\right.$ cells) were cultured and treated with various concentrations of Nef or together with different concentrations of N15P for 24 - 48 $\mathrm{h}$ and then the percent cell mortality was measured by the TUNEL assay using Rcho Apoptosis Kit. Apoptotic cells were then assessed as the percentage of TUNEL positive cells per 100 cells in each slide using a light microscope. The data were expressed as the average of triplicates $( \pm S D)$.

\section{Western blotting}

The extraction and isolation of nuclear and cytoplasmic protein were performed according to the nuclear and cytoplasmic protein extraction kit (Beyotime, China) and the concentration of protein was measured using enhanced BCA protein assay kit (Beyotime, China). For western blotting, $30 \mu \mathrm{g}$ of total protein was separated by $12 \%$ SDS-PAGE in a Tris/ $\mathrm{HCl}$ buffer system for $90 \mathrm{~min}$ at $90 \mathrm{~V}$, transferred onto PVDF membranes (Bio-Rad, USA), and incubated with rabbit anti-FOXO3a $(1: 1000)$ or anti-phosphoFOXO3a $\left(\mathrm{Ser}^{253}\right)$. Mouse anti-rabbit IgG (1:5 $000)$ was used as second antibody. Membranes were washed with TBS-T and incubated in enhanced chemiluminescence detection reagents (Amersham, Sweden) to visualize the proteins of interest. Densitometric analysis was 
performed using the Gel-Pro Application (version 4.0.0.4).

The effect of siRNA on Jurkat cells and PBMCs

FOXO3a suppression was accomplished using FoxO3a siRNA I (Cell Signaling Technology, USA) and Control siRNA (Unconjugated). SiRNAs $(100 \mathrm{nM})$ were transfected into exponentially growing Jurkat cells and PBMCs with siRNA transfection reagent (Santa Cruz Biotechnology, USA), according to the manufacturer's protocols. After $72 \mathrm{~h}$ of cell exposure to siRNAs, parallel siRNA-treated cells were analyzed for the presence of apoptosis by TUNEL staining.

\section{Statistical analysis}

Data were expressed as mean values \pm standard deviation (SD), and the statistical significance between testing and control groups was analyzed with GraphPad Prism 5.0. When two groups were compared, the unpaired Student's ttest was used. When multiple groups were evaluated, one-way ANOVA was used. $p<0.05$ was considered to be statistically significant.

\section{RESULTS}

\section{Extracellular soluble HIV-1 Nef-mediated apoptosis of bystander $\mathrm{CD4}^{+} \mathrm{T}$ cells}

Evidences have shown that the level of soluble nef that circulates in HIV-1-infected individuals was $0-10 \mathrm{ng} / \mathrm{ml}$ [16]. So, we first examined the apoptosis effect induced by extracellular soluble HIV-1 nef in vitro, and observed that Nef resulted in significant apoptosis in a dose- and timedependent manner in Jurkat cells. Since Jurkat cells are immortalized lymphocytic cells, we further investigated the apoptotic effects of extracellular HIV-1 Nef on primary PBMCs. Our study showed that extracellular soluble Nef protein induced apoptosis in human PBMCs in a dose and time dependent manner, which was consistent with the results in Jurkat cells (Fig 1).

\section{N15P inhibited the apoptosis induced by HIV- 1 extracellular soluble Nef}

The interaction of ${ }^{125}$ I-nef with Jurkat cells was inhibited by N15P in a dose-dependent manner, with $I_{50}$ value of $0.3516 \mathrm{ng} / \mathrm{ml}$ (Fig 2A). Following this we examined the effect of N15P on the extracellular soluble HIV-1 Nef-induced apoptosis. The apoptotic activity of extracellular Nef protein on Jurkat and human PBMCs were suppressed after pretreatment with N15P, which was in a time- and dose-dependent manner (Fig 2B).

\section{Critical involvement of FOXO3a signaling in bystander apoptosis induced by Nef}

On treating the cells with Nef, the phosphorylation level of FOXO3a in Jurkat cells and human PBMCs was decreased in timedependent manner, and FOXO3a was predominantly localized in the nucleus (Fig 3A, B and $E$ ). When Jurkat cells were pretreated with $0.5-2.5 \mathrm{ng} / \mathrm{ml} \mathrm{N} 15 \mathrm{P}$ for $4 \mathrm{~h}$, and then given 5 $\mathrm{ng} / \mathrm{ml}$ Nef, which is the middle level of soluble Nef that circulates in HIV-1-infected individuals, we found that N15P up-regulated the phospho$\mathrm{FOXO3a}$ and $\mathrm{FOXO} 3 \mathrm{a}$ was lesser localized in the nucleus (fig 3C, D and F). Moreover, we further silenced the transcriptional active form of FOXO3a, and the results indicated that FoxO3a siRNA led to a significant reduction in apoptosis (Fig 3G).
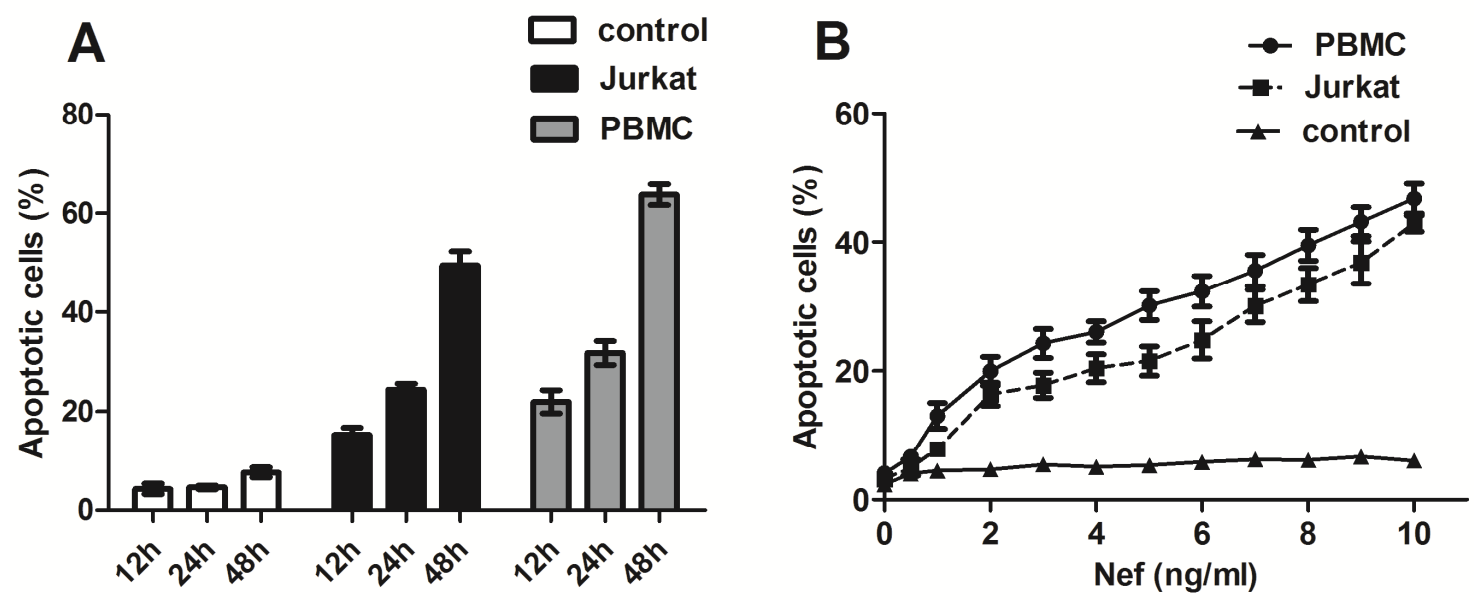

Figure 1: The apoptosis induced by extracellular HIV-1 nef protein; (A) apoptosis induced by $5 \mathrm{ng} / \mathrm{ml}$ extracellular HIV-1 nef protein; (B) apoptosis induced by $0-10 \mathrm{ng} / \mathrm{ml}$ nef protein at $36 \mathrm{~h}$ 
A

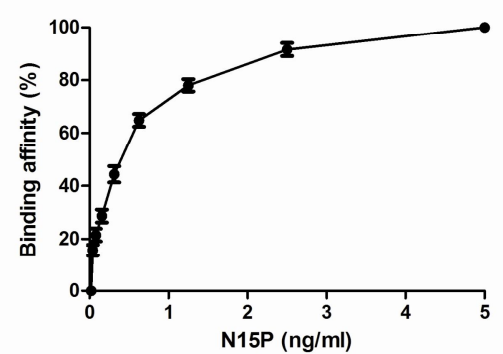

B

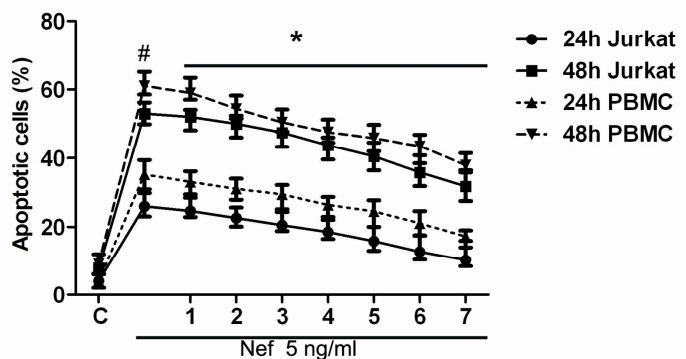

Figure 2: Inhibition of extracellular soluble Nef-induced apoptosis by N15P in vitro; $(A)$ the potential competitive binding effect of N15P against Nef; (B) apoptosis analysis by TUNEL staining. Note: $\mathrm{C}=$ control; $1=0.78125$ $\mathrm{ng} / \mathrm{ml} \mathrm{N} 15 \mathrm{P} ; 2=0.15625 \mathrm{ng} / \mathrm{ml} \mathrm{N} 15 \mathrm{P} ; 3=0.3125 \mathrm{ng} / \mathrm{ml} \mathrm{N15P} ; 4=0.625 \mathrm{ng} / \mathrm{ml} \mathrm{N} 15 \mathrm{P} ; 5=1.25 \mathrm{ng} / \mathrm{ml} \mathrm{N} 15 \mathrm{P} ; 6=$ $2.5 \mathrm{ng} / \mathrm{ml} \mathrm{N} 15 \mathrm{P} ; 7=5 \mathrm{ng} / \mathrm{ml}$ N15P); ${ }^{*} p<0.05$ vs the $5 \mathrm{ng} / \mathrm{ml}$ Nef group, \#p $<0.05$ vs control group

A

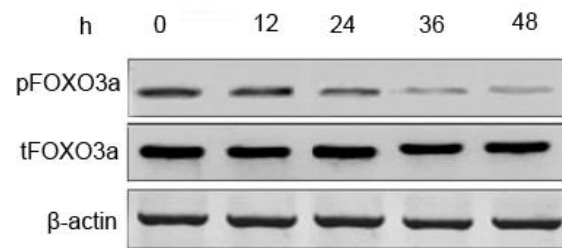

C

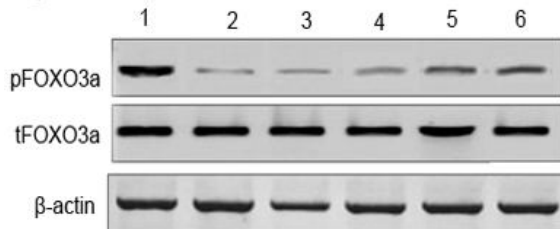

E
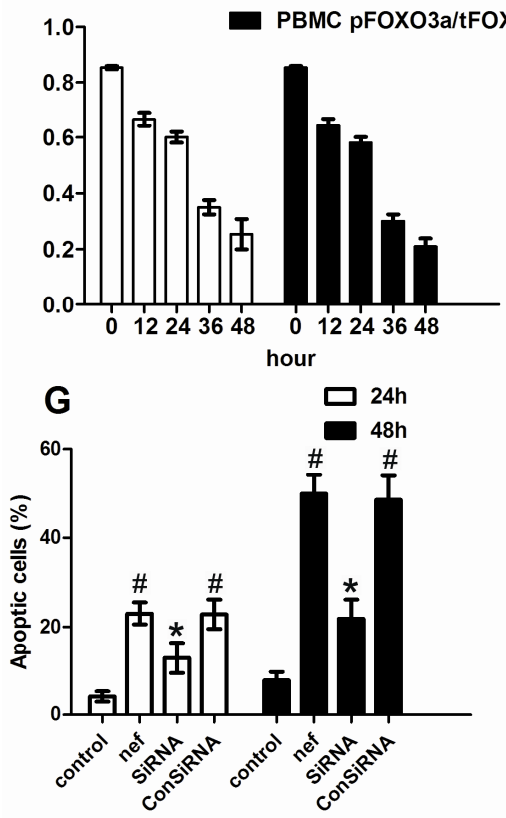

B

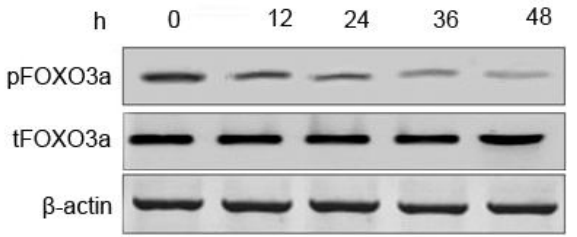

D

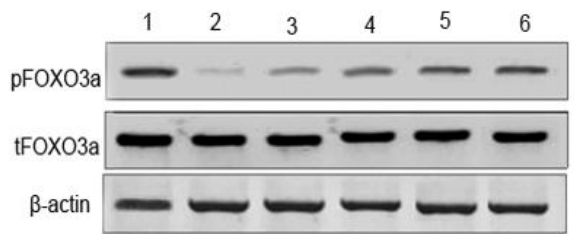

F $\square$ Jurkat pFoxo3a/tFoxo3a
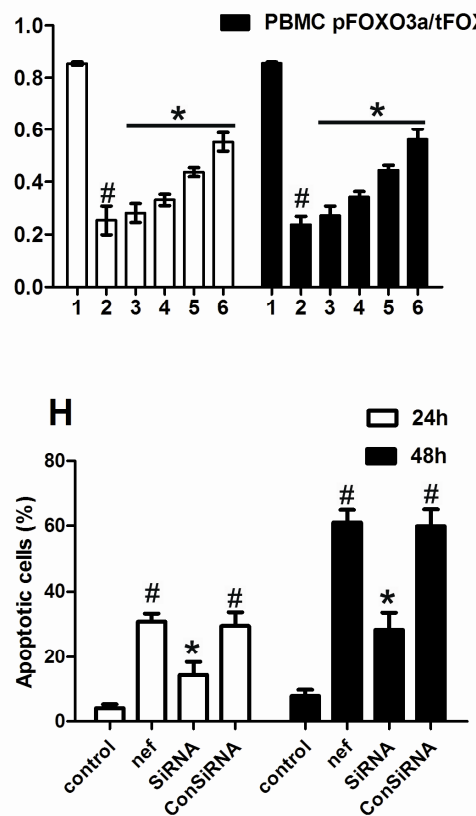

Figure 3: The level of p-FOXO3a and nuclear FOXO3a; (A) Western blotting analyses of Jurkat cells treated with $5 \mathrm{ng} / \mathrm{ml}$ Nef; (B) Western blotting analyses of PBMCs treated with $5 \mathrm{ng} / \mathrm{ml} \mathrm{Nef;} \mathrm{Western} \mathrm{blotting} \mathrm{analyses} \mathrm{of}$ Jurkat cells (C) and PBMCs (D) treated with Nef and N15P, $1=$ control, $2=5 \mathrm{ng} / \mathrm{ml} \mathrm{Nef,} 3=5 \mathrm{ng} / \mathrm{ml} \mathrm{Nef}+0.5$ $\mathrm{ng} / \mathrm{ml} \mathrm{N} 15 \mathrm{P}, 4=5 \mathrm{ng} / \mathrm{ml} \mathrm{Nef}+1.0 \mathrm{ng} / \mathrm{ml} \mathrm{N} 15 \mathrm{P}, 5=5 \mathrm{ng} / \mathrm{ml} \mathrm{Nef}+1.5 \mathrm{ng} / \mathrm{ml} \mathrm{N} 15 \mathrm{P}, 6=5 \mathrm{ng} / \mathrm{ml}$ Nef $+2.5 \mathrm{ng} / \mathrm{ml}$ N15P; (E, F) Densitometric analysis of pFoxo3a/tFoxo3a; the percentage of Jurkat cells $(G)$ and PBMCs $(H)$ apoptosis by silencing the transcriptional active form of FOXO3a; Note: nef $=5 \mathrm{ng} / \mathrm{ml}$ nef, SiRNA $=$ SiRNA FOXO3a $+5 \mathrm{ng} / \mathrm{ml}$ nef, ConSiRNA = ConSiRNA FOXO3a $+5 \mathrm{ng} / \mathrm{ml}$ nef. ${ }^{*} p<0.05$ vs the $5 \mathrm{ng} / \mathrm{ml}$ Nef group; \#p < 0.05 vs control group 


\section{DISCUSSION}

The G-protein coupled receptor CXCR4 is a coreceptor for HIV-1 infection and is involved in the process of HIV-encoded proteins-induced uninfected $\mathrm{CD}^{+} \mathrm{T}$ cells apoptosis, such as gp120 and nef. The diverse role of the SDF1/CXCR4 axis in the pathogenesis of HIV has established CXCR4 as a promising therapeutic target [17]. The earliest efforts to find CXCR4 antagonists focused mainly on peptide derivatives, the future perspective on the development of CXCR4 antagonists is the low molecular CXCR4 antagonists [18]. Therefore, N15P was modified by structurally matching, downsizing, and reduction of peptide character in an attempt to develop a new low-molecular weight CXCR4 antagonist that would show remarkable inhibitory activity against entry of HIV into cells.

The extracellular HIV-1 nef protein is synthesized early during the initial viral infection and could contribute to the depletion of uninfected $\mathrm{CD}^{+} \mathrm{T}$ lymphocytes by directly interacting with CXCR4 $[6,7]$. In this study, we report that the 15 amino acid peptide (N15P) derived from the $\mathrm{N}$-terminal of VMIP-II inhibits the apoptosis of $\mathrm{CD}^{+} \mathrm{T}$ lymphocytes induced by extracellular HIV-1 Nef protein in vitro. Dose-response and time course assays revealed that $\mathrm{N} 15 \mathrm{P}$ significantly reduced the apoptosis of cells induced by Nef protein in both Jurkat and human PBMCs. The explanation for this inhibition is that the antagonist N15P physically blocks the Nef-induced apoptosis through competitive binding to CXCR4.

Evidences have shown that a low level of Nef could cause continued, albeit slower, depletion of $T$ cells [7], but little is known about the nefCXCR4 downstream signaling pathways and how they contribute to disease progression. FoxO3a is a member of the FoxO subfamily of forkhead (fox) transcription factors, and the induction of $\mathrm{FOXO} 3 \mathrm{a}$ results in the activation of the apoptotic intrinsic (via Bim) and extrinsic (via FasL and TRAIL) pathways [19]. In this present study, the results have shown that treatment of Jurkat cells and PBMCs with Nef protein resulted in the accumulation of $\mathrm{FOXO3a}$ in the nucleus and low level of p-FOXO3a.

Pretreatment of Jurkat cells with N15P resulted in activation of p-FOXO3a, suggesting that N15P caused an enhancement of phosphorylated FOXO3a levels, which lead to the FOXO3a nuclear export. When endogenous FOXO3a was knocked down in cells by RNAi, the percentage of apoptosis reduced suggesting that $\mathrm{FOXO3a}$ has a pivotal role in Nef-induced apoptosis. It indicates that FOXO3a appears to be a critical factor regulating Nef-induced lymphocytes apoptosis [20]. In addition, pretreatment Jurkat cells with the N15P increased FoxO3a phosphorylation levels and FoxO3a nuclear export, which consequently decreased the apoptosis of Jurkat cells.

Apoptosis is controlled by a variety of cell signals, which may exhibit a substantial crosstalk between each other. In this present study, the apoptosis induced by the extracellular soluble HIV-1 Nef was not fully abolished by FOXO3a siRNA. So, there may be other signal pathways involved in Nef-induced apoptosis and FOXO3a mechanism may not be the only factor involved in the maintenance of Jurkat and PBMCs survival in response to Nef protein. Hence, it will be important to determine whether polymorphisms along the FOXO3a pathway are responsible for Nef-induced bystander apoptosis and more research work should be devoted to unravel the mechanisms of induction of apoptosis by Nef.

\section{CONCLUSION}

N15P significantly impedes the rate and levels of apoptosis induced by extracellular soluble HIV-1 Nef, and therefore can reduce virus-associated pathogenesis. The activation of FOXO3a phosphorylation is at least in part responsible for the HIV-1 extracellular soluble Nef-mediated death of the uninfected cell. More importantly, othe findings provide new insight into the mechanism of the extracellular soluble HIV-1 Nef induced apoptosis. However, more insight is needed into the molecular mechanisms involved in the apoptosis induced by Nef in vitro and in vivo. Further studies along these lines are currently ongoing.

\section{ACKNOWLEDGEMENT}

This study was supported by the National Science Foundation of China (NSFC no. 3087221), Guangdong Province Major Projects of Key Areas (YS No, 2005/162), and Major Technology Program Funded Projects, Guangzhou (no. 2011Y1-00017-3). Gui-Jie An and Xiu-Ying $\mathrm{Li}$ are first co-authors of this paper.

\section{REFERENCES}

1. Laurent-Crawford $A G$, Krust $B$, Rivière $Y$, Desgranges $C$, Muller S, Kieny MP, Dauguet C, Hovanessian AG. Membrane expression of HIV envelope glycoproteins triggers apoptosis in CD4 cells. AIDS Res Hum Retroviruses 1993; 9: 761-773.

Trop J Pharm Res, May 2014; 13(5): 687 
2. New DR, Ma M, Epstein LG, Nath A, Gelbard HA. Human immunodeficiency virus type 1 Tat protein induces death by apoptosis in primary human neuron cultures. J Neurovirol 1997; 3: 168-173.

3. Strack PR, Frey MW, Rizzo CJ, Cordova B, George HJ, Meade R, Ho SP, Corman J, Tritch R, Korant BD. Apoptosis mediated by HIV protease is preceded by cleavage of Bcl-2. Proc Natl Acad Sci USA 1996; 93: 9571-9576.

4. Jacotot E, Ravagnan L, Loeffler $M$, Ferri $K F$, Vieira $H L$, Zamzami N, Costantini P, Druillennec S, Hoebeke J, Briand JP, et al. The HIV-1 viral protein $R$ induces apoptosis via a direct effect on the mitochondrial permeability transition pore. J Exp Med 2000; 191: 33-46.

5. Rasola A, Gramaglia D, Boccaccio C, Comoglio PM. Apoptosis enhancement by the HIV-1 Nef protein. $J$ Immunol 2001; 166: 81-88.

6. Huang MB, Jin LL, James CO, Khan M, Powell MD, Bond VC. Characterization of Nef-CXCR4 interactions important for apoptosis induction. J Virol 2004; 78: 11084-11096.

7. James CO, Huang MB, Khan M, Garcia-Barrio M, Powell $M D$, Bond VC. Extracellular Nef protein targets CD4+ $T$ cells for apoptosis by interacting with CXCR4 surface receptors. J Virol 2004; 78: 3099-3109.

8. Lenassi $M$, Cagney $G$, Liao $M$, Vaupotic $T$, Bartholomeeusen $K$, Cheng $Y$, Krogan NJ, Plemenitas A, Peterlin BM. HIV Nef is secreted in exosomes and triggers apoptosis in bystander CD4+ T cells. Traffic 2010; 11: 110-122.

9. van Grevenynghe J, Procopio FA, He Z, Chomont N, Riou C, Zhang Y, Gimmig S, Boucher G, Wilkinson $P$, Shi $Y$, et al. Transcription factor FOXO3a controls the persistence of memory CD4(+) T cells during HIV infection. Nat Med 2008; 14: 266-274.

10. van Grevenynghe J, Cubas RA, Noto A, DaFonseca $S$, He Z, Peretz Y, Filali-Mouhim A, Dupuy FP, Procopio $F A$, Chomont $N$, et al. Loss of memory $B$ cells during chronic HIV infection is driven by Foxo3a- and TRAIL-mediated apoptosis. J Clin Invest 2011; 121: 3877-3888

11. Cui $M$, Huang $Y$, Zhao $Y$, Zheng J. Transcription factor FOXO3a mediates apoptosis in HIV-1-infected macrophages. J Immunol 2008; 180: 898-906.
12. Kledal TN, Rosenkilde MM, Coulin F, Simmons G, Johnsen AH, Alouani S, Power CA, Lüttichau HR, Gerstoft J, Clapham PR, et al. A broad-spectrum chemokine antagonist encoded by Kaposi's sarcomaassociated herpesvirus. Science 1997; 277: 16561659.

13. Ye Sh-D, Mo $X M$, Zhang $G$, Li XY, Wang $F$, Sun $H X$. Analysis of receptor-binding proper ties of VMIP- II. Zhongguo Xian Dai Yi Xue Za Zhi 2006; 16: 35463552.

14. Mo XM, Sun $H X$. The effects and mechanisms of CXCR4 antagonist-N15P peptide on LPS-induced inflammation [dissertation]. [Rochester]: Jinan University; 2012 Apr. 27p-28p.

15. Jurcevic S, Praud C, Coppin HL, Bertrand A, Ricard S, Thomsen M, Lakhdar-Ghazal F, De Preval C. Role of polymorphic residues of human leucocyte antigen-DR molecules on the binding of human immunodeficiency virus peptides. Immunology 1996; 87: 414-420.

16. Fujii $Y$, Otake $K$, Tashiro M, Adachi A. Soluble Nef antigen of HIV-1 is cytotoxic for human CD4+ $T$ cells. FEBS Lett 1996; 393: 93-96.

17. Hashimoto C, Tanaka $T$, Narumi $T$, Nomura $W$, Tamamura $H$. The successes and failures of HIV drug discovery. Expert Opin Drug Discov 2011; 6: 1067-1090.

18. Tamamura $H$, Tsutsumi $H$, Masuno $H$, Fujii $N$. Development of low molecular weight CXCR4 antagonists by exploratory structural tuning of cyclic tetra- and pentapeptide-scaffolds towards the treatment of HIV infection, cancer metastasis and rheumatoid arthritis. Curr Med Chem 2007; 14: 93102.

19. Barthélémy C, Henderson CE, Pettmann B. Foxo3a induces motoneuron death through the Fas pathway in cooperation with JNK. BMC Neurosci 2004; 5: 48.

20. Riou C, Yassine-Diab B, Van grevenynghe J, Somogyi $R$, Greller LD, Gagnon D, Gimmig S, Wilkinson $P$, Shi $Y$, Cameron MJ, et al. Convergence of TCR and cytokine signaling leads to FOXO3a phosphorylation and drives the survival of CD4+ central memory $T$ cells. J Exp Med 2007; 204: 79-91. 